UDC 502.4+911+004.9

Olga V. Alokhina ${ }^{1}$, Associate Research Scientist

ORCID ID 0000-0002-5537-2720 e-mail: alokhina2011@gmail.com

Oleg L. Ivantyshyn ${ }^{1}, \mathrm{PhD}$, Senior Researcher

ORCID ID 0000-0002-2340-6463 e-mail: oliv@ipm.lviv.ua

Mykola M. Korus ${ }^{1}$, Engineer

ORCID ID 0000-0002-8014-5378 e-mail: nikkor2005@ rambler.ru

Volodymyr V. Koshovyy ${ }^{1}, \mathrm{PhD}$, Leading Researcher

ORCID ID 0000-0002-4321-4266 e-mail: koshovy@ipm.lviv.ua

Mykhailo O. Popov ${ }^{2}$, ScD, Professor

ORCID ID 0000-0003-1738-8227 e-mail: mpopov@ casre.kiev.ua

Bohdan P. Rusyn ${ }^{1}$, ScD, Professor

ORCID ID 0000-0001-8654-2270 e-mail: rusyn@ipm.lviv.ua

${ }^{1}$ Karpenko Physico-Mechanical Institute of the NAS of Ukraine, Lviv, Ukraine

${ }^{2}$ State Institution Scientific Centre for Aerospace Research of the Earth of the Institute of Geological Science of the NAS of Ukraine, Lviv, Ukraine

\title{
INFLUENCE OF NATURAL CLIMATIC FACTORS ON LAKES WATERS FLUCTUATIONS IN NATURE PROTECTED AREAS
}

\begin{abstract}
The question of "helio-dependence" of water level fluctuations within the closed type lakes in the West Polesie nature protected areas has been considered in the paper. The method of correlation analysis was used to define the interrelation between helio- and geophysical processes in the part that provides the ecological safety of the territory. The analysis has shown that the Total Solar Irradiance Index is more informative than the one including sunspot numbers.

Keywords: nature protected area; closed type lake; water level fluctuations; "heliodependence"; sunspot numbers; total solar irradiance; amount of precipitation
\end{abstract}

\section{Introduction}

While the development of activities providing the ecological safety within the nature protected areas (NPA) it's necessary to take into account not only the influence of anthropogenic factors, because the last are often restricted by a current legislation. Today, with the intensification of nature climatic factors (NCF), the problem of their influence evaluation on the ecological stability within NPA is very urgent, especially in the context of providing their ecological stability. Among the NCF effects the most important are those, which are conditioned by factors of space origin, namely, solar activity (SA) processes that influence the components within the nature protected areas. A concept and structure of solar-terrestrial links (STL) studies are developed by organizations-participants of Shatsk Interdepartmental Research Ecological Laboratory of the NAS, MES and NAFR of Ukraine (Fig. 1) [1-3].

(c) O.V. Alokhina, O.L. Ivantyshyn, M.M. Korus, V.V. Koshovyy, M.O. Popov, B.P. Rusyn, 2018 
Estimation a degree of "helio-dependence" of water level fluctuations within the closed type lakes is one direction for study, proposed in the concept. Water balance of these type lakes is formed only by underground sources and meteorological conditions. Also, their functioning is characterized by quasi-stationarity, ecological stability and self-regularity.

The importance of such studies within the West Polesie nature protected areas is results from some kind of inconsistency of up to date estimations of these lakes water levels long-term dynamics and the reasons of their fluctuations. The main issue is the following: is it the result of water level fluctuations caused by nature factors or by man-made intervention into the hydrology? [3].

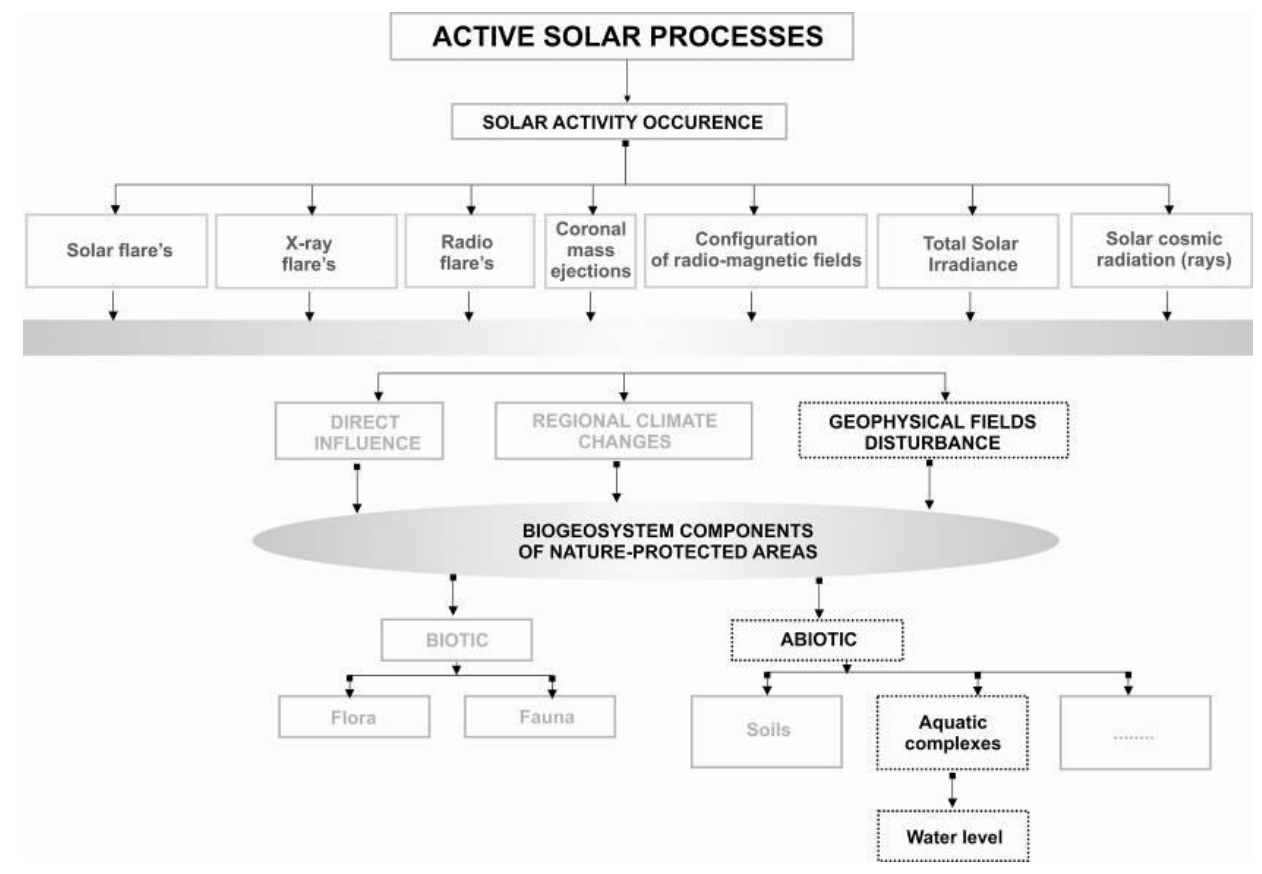

Fig. 1 - A concept of studying the solar-terrestrial links within the nature protected areas

Moreover, a long-term prediction of Svityaz Lake water level, from the ecological safety point of view, is also a topical issue owing to the fact that this lake is the main source of fresh water for ensuring the sustainability of this region.

\section{State of Research}

In the present-day science there is an opinion that it's necessary to take into account the influence of space factors, especially SA processes, on geosphere and biosphere components. Even V.I. Vernadsky has emphasized that their organization is an elements of space origin [4]. There is a system of direct and indirect physical links between helio- and geophysical processes. The Earth receives from the Sun not only light and heat what provide sufficient level of lightening and temperature of its surface and therefore provides ecosystems stability. Also, the surface is influenced by the ultraviolet and $\mathrm{x}$-ray, solar wind, solar and galactic cosmic rays etc. Variations of the above-mentioned factors power being influenced by SA, lead to a chain of 
interdependent phenomenon within the interplanetary space, namely, magnetosphere, ionosphere, neutral atmosphere, biosphere, geosphere (hydrosphere, upper lithosphere) of the Earth.

Two main aspects of solar-terrestrial links (STL) are considered, namely: energy when the influence is limited by the transfer of energy, emitted during non-stationary processes on the Sun; informational - when the influence is limited by the redistribution of energy, accumulated in magnetosphere, ionosphere and neutral atmosphere of the Earth [5]. V.I. Vernadsky was one of the first who showed that geosphere (biosphere) evolution proceeds under the influence of space physical factors. Moreover, cosmic rhythms influence the terrestrial processes on all levels of geo- and biosphere organization. Thanks to his fundamental researches, such naturescientific problems as "Sun-climate-geosphere" and "Sun-biosphere" were outlined, in the frames of which, the problem of solar activity processes "geoefficiency" was studied $[6,7]$.

Anyway, most of the terrestrial processes depend on cyclical changes of SA level. Today, solar cycles (SC) with the following periods are confirmed, namely: 11 years (most distinct), 22 (double), 30-40 (Briknerovskyy), 80-90 (century-old), 500 and 1800-1900 years. Therefore, it's natural to assume the existence of solar origin cycles in the water level fluctuations of closed type lakes. Investigations on SA processes "geoefficiency" within the "Sun-climate-geosphere" system show the intensification or weakening of geophysical processes during the solar cycle's maxima and minima [6, 7].

The aforesaid can be also applied to dynamics of closed type lakes water levels what is considered in scientific papers on the example of Patzcuaro Lake (Mexico), Chudske (Estonia) and others [8-12]. Above-mentioned papers describe general cycles, characterizing the water level fluctuations of closed types lakes and SA parameters changes within different ranges. Long-term (> 11 years) and short-term (2-4 years) fluctuations of these processes were studied using spectral and autoregressive spectral analysis. Analyses included parameters describing monthlyaverage $\mathrm{SA}$ values (sunspot area, index $\mathrm{F}_{10,7}$, $\mathrm{HL}$-index etc.), cosmic rays and water levels for the period 1850-1992. As the result, one can point out the following: statistically significant variations of water levels with periods equal to 2.6-4.1, 9-11.2, 22 and 80-90 years; delay of time fluctuations of solar activity maximum towards minimum - 3-4 years; predominance of 22-years solar cycle in hydrological processes etc. $[8,9,11]$.

\section{Materials and methods}

Studies on "helio-dependence" of water-level of closed type lakes within the West Polesie nature protected areas of Ukraine were started in Karpenko PhysicoMechanical Institute of the NAS of Ukraine at the beginning of 2000 [13]. In the present paper these studies are continued for the period of 22-24 solar cycles for Svityaz Lake. Also, previously obtained results on dependences between Svityaz Lake water level $H_{0}$ and SA, amount of precipitations $V$ and air temperature $T_{n}{ }^{0} C$ [13], as well as more general dependencies between space- and geophysical parameters for 18-21 SC period are taken into account $[14,15]$.

The present studies are developed by authors based on regional geophysical (hydrological, climatic) processes and helioprocesses data, which cover the 
22-24 SC periods. Among them: average annual values of air temperature $T_{\text {a.avr. }}$. (1929-2004, 1985-2005, 1969-2017, 2010-2017); average monthly values of $H$ (2010-2017) $(H$ - distance from a fixed point to water mirror; increasing of which means the decreasing of Svityaz water level $H_{0}$ ); amount of precipitations $V$; Wolf-number $W$ and Total Solar Irradiance TSI data from 7 satellites that cover 1978-2017.

Interaction of solar radiation with atmosphere, geosphere and Earth hydrosphere defines the weather and climatic regimes of the Earth. Therefore, TSI variability monitoring is the important part of studies in the field of climate changes, especially in the context of SA influence on water levels of closed type lakes. From 1978, NOAA (National Centers for Environmental Information) forms the TSI database using the direct satellite monitoring (7 experiments: Nimbus7 / ERB1, SMM / ACRIM12, ERBS / ERBE3, UARS / ACRIM24, SOHO / VIRGO5, ACRIMSAT / ACRIM36 and SORCE / TIM7) [15]. The analysis of the above-mentioned database proves that both SA and TSI are the internal changeable phenomena. Moreover, changes of TSI are a dominant stimulus for climate changes. Periodicity of these changes (Fig. 2) points to the fact that solar power influence on climate would dominate and in the future too.

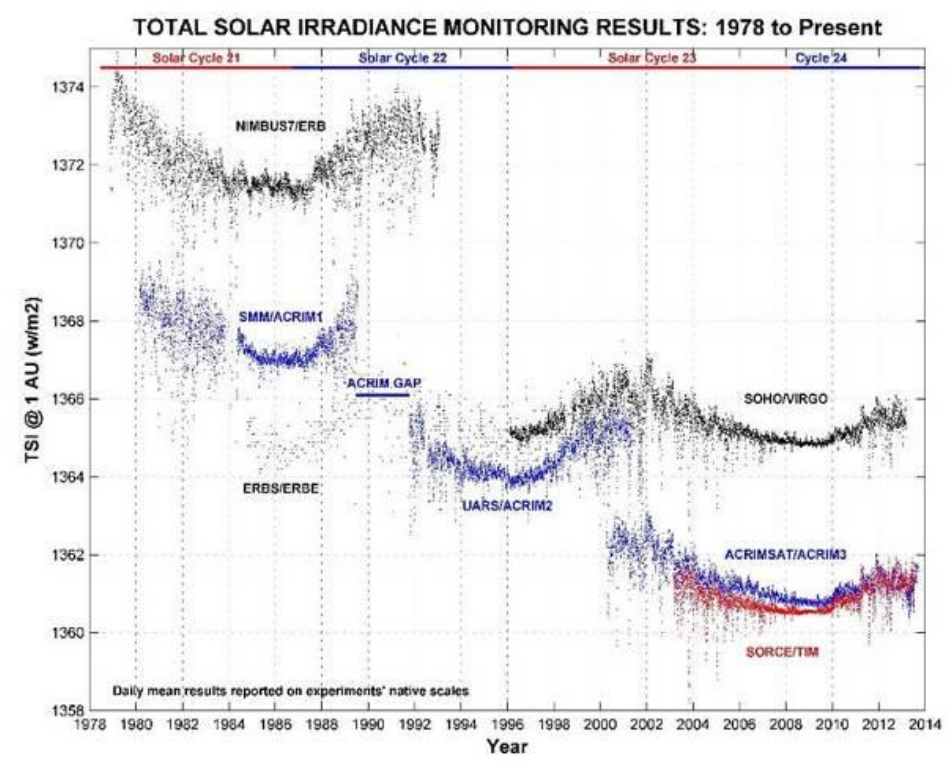

Fig. 2 - TSI satellite monitoring results during 1978-2014

Figure 3 and 4 show a long-term dynamics of $H_{0}$ for Svityaz Lake and regional $T_{\text {a.avr. }}$ during 22-24 solar cycles, accordingly. Dynamics of relative changes of $\delta W$ (relative to the maximum in $22 \mathrm{SC}$ ), $\delta H_{0}$ (relative to maximum difference of average annual water level above the sea level during 22-24 $\mathrm{SC}$ ) and $\delta V$ (relative to maximum difference of precipitations average annual amount during 22-24 SC) is shown on Fig. 5. 


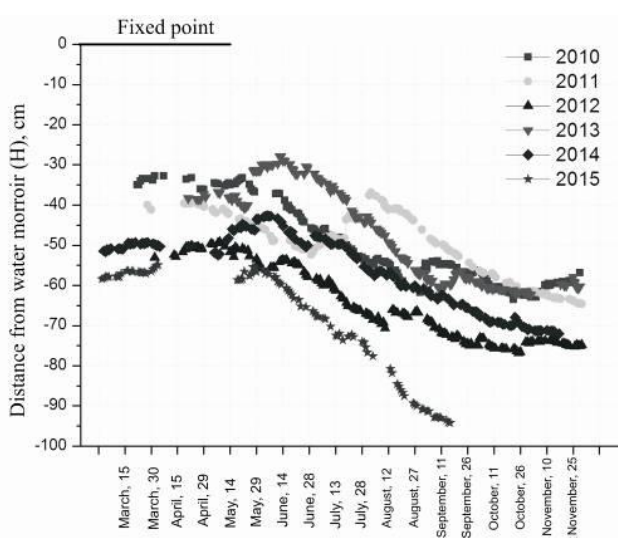

Fig. 3 - Dynamics of water level $H_{0}$ monthly fluctuations in Svityaz Lake (relative to fixed point) during 2010-2017

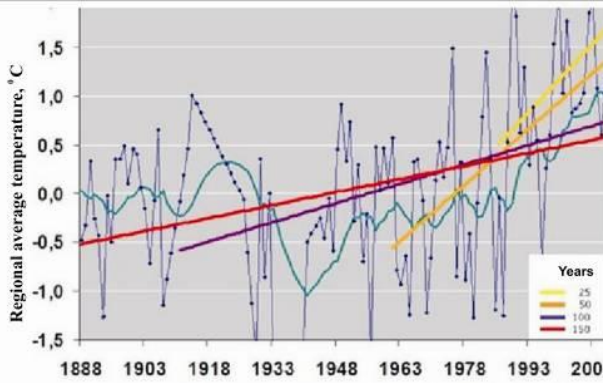

Fig. 4 - Changes of regional average annual air temperature $T_{\text {a.avr. }}$ and their

linear approximation during last 120, 100, 45 and 25 years (different inclination angles)

The above data of studies include the following important information, namely:

- low water levels were observed during last two years (March-November, 2016-2017) as compared with previous one (2010-2017); the difference between water levels in March, 2010 and 2016 is more than $10 \mathrm{~cm}$;

- the increase in global temperature is $0,35^{\circ} \mathrm{C}$ during $1910-1940$ and regional for the period 1986-2011 is 4,3 times more;

- one can observe a "synchronicity" in changes over time of the annual average and relative $W$ and $H_{0}$ values that may indicate on "helio-dependence" of Svityaz Lake water level changes (Fig. 5).

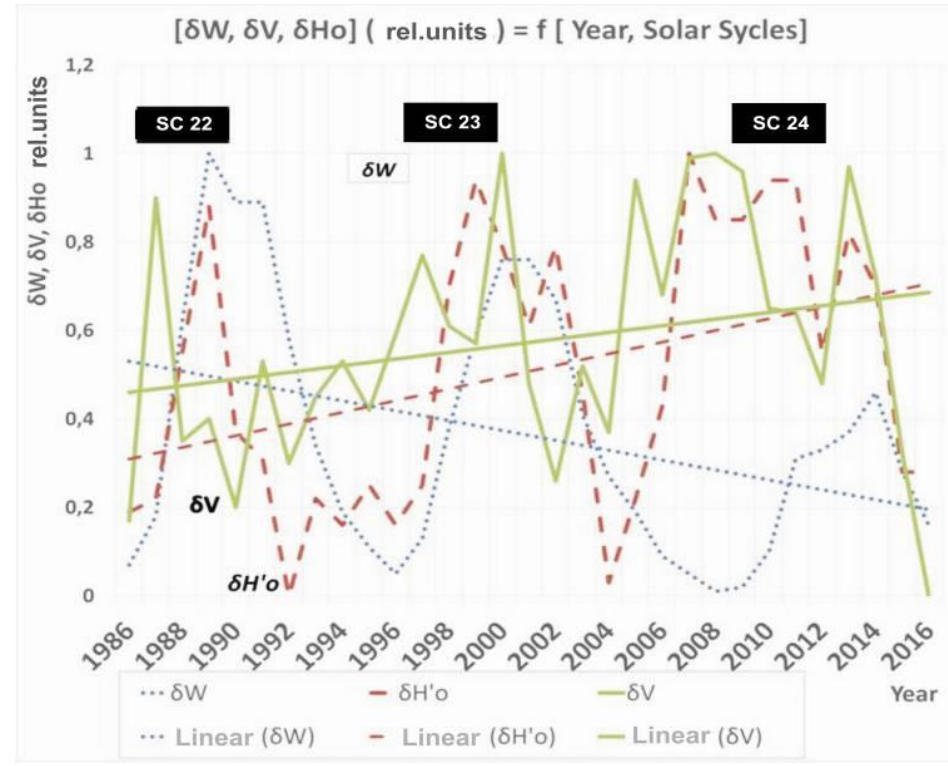

Fig. 5 - Relative changes (relative units) of Wolf number $\delta W$, amount of precipitations $\delta \mathrm{V}$ and water level $\delta H_{0}$ average annual values as well as their linear trends during 22-24 SC 
The main task of current researches is to assess the degree and dynamics of dependencies (according the correlation coefficients $r-r_{v / w}, r_{H_{0} / V}, r_{H_{0} / W}=\int(W, S C)$ ) between average annual values of $H_{0}, W, T S I$ and regional climate $V$, $T_{\text {a.avr. }}, T_{\text {a.max }}$ during 22-24 SC and to compare them from the point of their influence on ecological state and safety of natural environment.

\section{Results and discussions}

A spectral-correlation analysis was used to study the "helio-dependency" of Svityaz Lake water level fluctuations. Basing on calculations of correlation coefficients $r$ between $H_{0}, W, V$ and TSI, the following conclusions were formulated:

1. Svityaz Lake water system is a complicated fluctuating system with different periods of water level changes and long-term (multiple-year) tendencies of its changes. The last depend on many external factors, viz. climatic (air temperature, precipitations), solar processes etc. Regional microclimate, mainly, influences the water level seasonal fluctuations (the water level during March-November 2010-2017 decreased as compared to 2015 by $39,3 \mathrm{~cm}$ ).

2. Results of previous studies during 1929-2004 had showed an explicit 11 years cycle in fluctuations spectrum of sunspot number $W$ and practically absent longterm 83 years cycle. Speaking about the analysis of water level fluctuations spectrum, one can note the existence of a long-term trend (83 years) of $H_{0}$ decreasing, what can be related to atmosphere circulations etc. (Fig. 6) [13]. Also, the existence of 8-12 years cycles within $H_{0}$ and $W$ fluctuations spectrums during 1929-2004 was proved, where in the 11 years cycles of $W$ and $V$ are almost similar and their correlation is equal to $r_{V / W} \approx 0.76$.

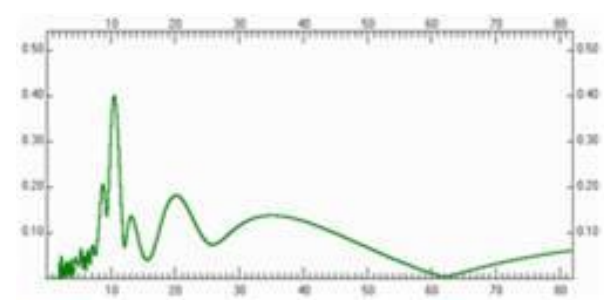

a)

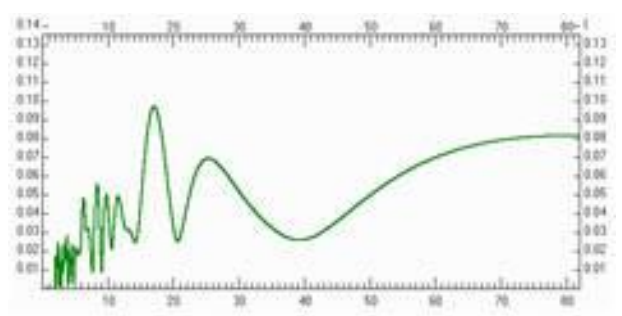

b)

Fig. 6 - Fluctuations spectrum: a) sunspot number $W$; b) Svityaz Lake water level $H_{0}$ ( $Y$ axis presents the amplitude in \% from the average value, $X$ axis - period, years)

3. Approximation of $\delta W, \delta V$ and $\delta H_{0}$ parameters changes during 22-24 SC (Fig. 5) and comparative analysis of their linear trends (Fig. 7) had showed a positive correlation between a long-term (during three SC) changes of $\delta H_{0}$ and $\delta V$ parameters as well as the negative correlation between $\delta H_{0}$ and $\delta W$ that indicates on strong dependence between Svityaz Lake water level and precipitations amount. 


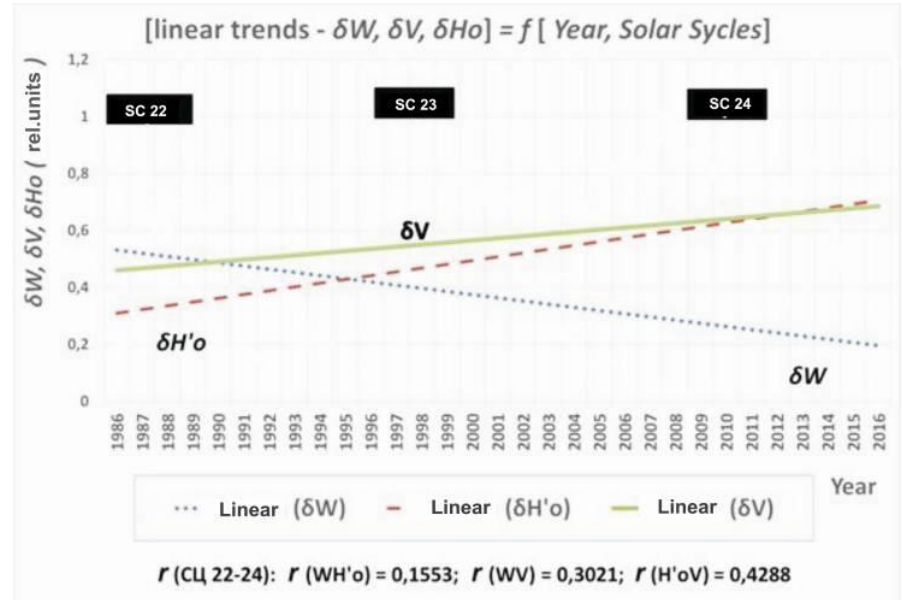

Fig. 7 - Linear approximation of relative changes trends during 22-24 SC (1986-2016) of average annual values: Wolf number $\delta W$, precipitations amount $\delta V$ and water level $\delta H_{0}$

4. The dynamics of water level relative fluctuations $\delta H_{0}$ (relative to maxima) and precipitations amount $\delta V$ had been defined within each 22-24 SC during the process of $W$ relative change increase and decrease (solid line) (Fig. 8a-8c) as well as their linear trends (dotted line). Figure $8 \mathrm{~d}$ showed the resulting graph of $\Delta H_{0} / \Delta V$ ratio changes covering 22-24 SC, which describe a dependency between $\Delta H_{0}$ and $\Delta V$ increase.

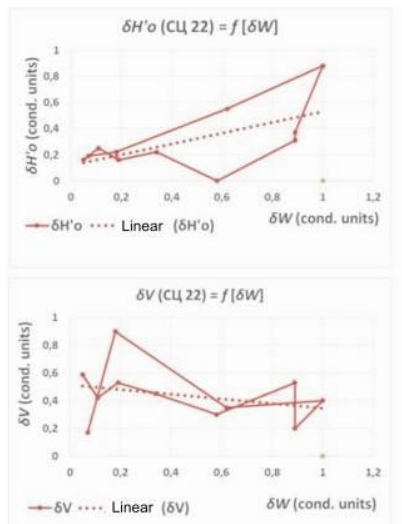

a)

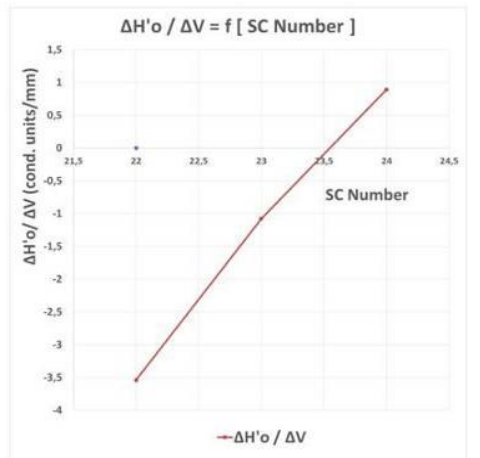

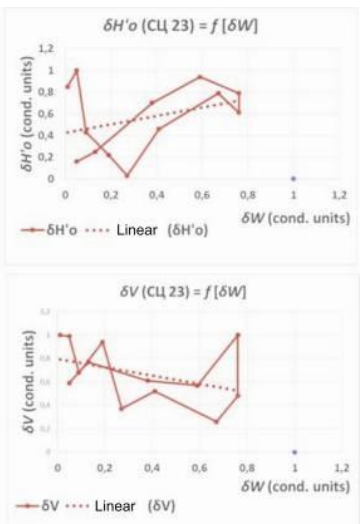

b)

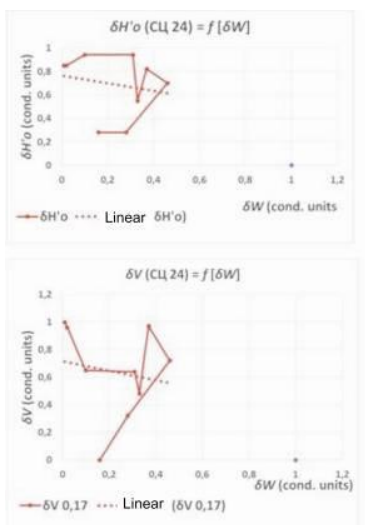

c)

Fig. 8 - Fluctuations dynamics of water level $\delta H_{0}$ and precipitations $\delta V$ relative changes towards maximum during each $\mathrm{SC}$ under the process of increase and decrease of $W$ relative change (dotted line-linear trends): a) in $22 S C, b)$ in $23 S C, c)$ in 24 $S C ; d)$ changes of $\Delta H_{0} / \Delta V$ ratio during 22-24 SC, which characterizes dependence between $\Delta H_{0}$ and $\Delta V$ increase

d) 
The above-mentioned graphs show that the dynamic of water level $H_{0}$ fluctuations and precipitations $V$ during the increase/decrease of $W$ has some similarity. At the stage of $W$ increase one can see the increase of $H_{0}$ and at the stage of $W$ decrease, $H_{0}$ also decreases. This experimental fact indicates the opportunity for a long-term forecasting the dynamics of closed type lakes water levels. Moreover, it provides the informational basis for ecological safety enhancement within the West Polesie nature-protected areas.

5. Comparison the dynamics of total solar irradiance relative changes $T S I\left(\delta T S I=\Delta T S I / T S I_{\max }\right)$ with relative changes of $\Delta H_{0}^{\prime}$ and $V$ (Fig. 9a) during 22-24 SC as well as the dynamics of such correlation coefficients as $r_{H_{0}^{\prime} / W}, r_{V / W}, r_{H / V}$ (Fig. 9b), evidences a significant influence of TSI on precipitations amount (close linear dependence of $\Delta H_{0}^{\prime}$ on $\Delta V$ and "synchronicity" progress of $\delta T S I$ and $\Delta V$ lines).

6. Figure 10 also indicates a considerable influence of total solar irradiance on water level of closed type lakes. It shows the contribution level of separate parameters of helio- and geophysical processes into the formation of solarterrestrial links helioefficiency level. It's demonstrated by the dependence between correlation coefficients $r_{H_{0}^{\prime} / W}, r_{V / W}, r_{H / V}, r_{H_{0}^{\prime} / T S I}$ and parameters, characterizing these processes (during 22-24 SC).

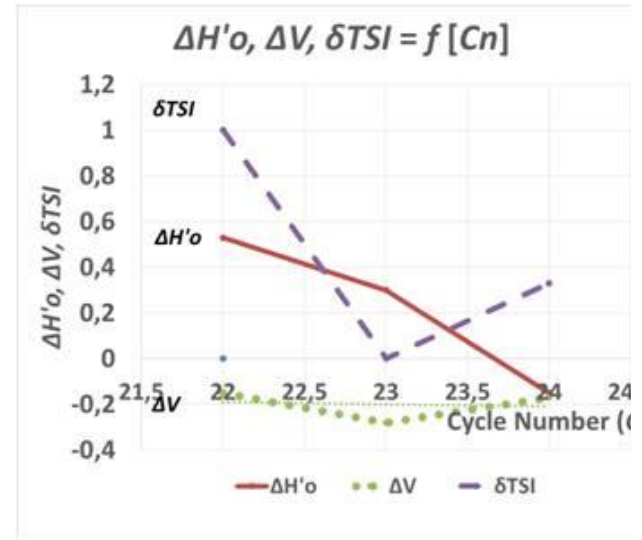

a)

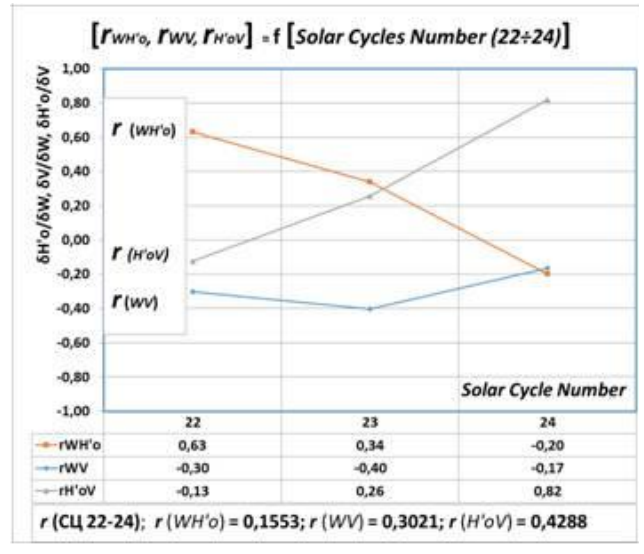

b)

Fig. 9 - Dynamics of changes during 22-24 SC (1986-2016) of:

a) relative changes of water levels $H_{0}^{\prime}$, precipitations $V$ and TSI; $b$ ) correlation coefficients between $H_{0}^{\prime}, V$ and $W$ 


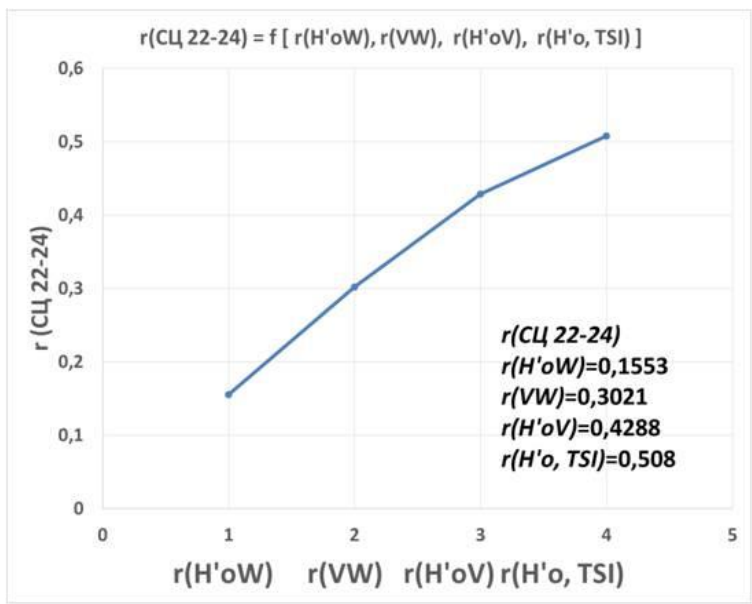

Fig. 10 - The dependence between correlation coefficients

$r_{H_{0}^{\prime} / W}, r_{V / W}, r_{H / V}, r_{H_{0}^{\prime} / T S I}$ and parameters, characterizing a helioefficiency of closed type lakes water level fluctuations

Thus, as solar irradiance, in fact, determines the density of radiated solar energy $\left(\mathrm{W} / \mathrm{m}^{2}\right)$ and, respectively, the temperature regime on the Earth surface, therefore it can be considered as a defining natural factor of space origin, influencing the "helio-dependency" of closed type lakes water level fluctuations within the West Polesie nature-protected areas.

\section{REFERENCES (TRANSLATED AND TRANSLITERATED)}

1. Panasyuk, V. V., Lyalko, V. I., \& Naida, V. V. (2009). Shatska mizvidomcha naukovodoslidna ekologichna laboratoriya: Organizaziya I programa diyalnosti. Nauk. Visnyk VDU Im. L. Ukrainky, (1), 116-122 (in Ukrainian).

2. Didukh, I. P., \& Popov, M. O. (2009). Rol Shatskoho natsionalnoho pryrodnoho parku v konteksti zavdan Derzhavnoi tsilovoi ekolohichnoi prohramy monitorynhu navkolyshnoho pryrodnoho seredovyshcha. Nauk. Visnyk VDU Im. L. Ukrainky, (1), 8-15 (in Ukrainian).

3. Alokhina, O. V., Koshovyi, V. V., \& Ivantyshyn, O. L. (2012). Vplyv soniachnoi aktyvnosti na ekolohichni protsesy na pryrodo-zapovidnykh terytoriiakh Zakhidnoho Polissia: Problema chy hipoteza? Nauk. Visnyk VDU Im. L. Ukrainky, 294-301 (in Ukrainian).

4. Shuhrina, S. M., \& Vzutyi, A. M. (1986). Soniachna aktyvnist i biosfera. Novosybirsk (in Russian).

5. Ivantyshyn, O. L., \& Koshovyi, V. V. (2016). Do otsiniuvannia heoefektyvnosti soniachnykh yavyshch. In Ukrainian Conference on Space Research, Odessa, Ukraine (p. 33). Kyiv, Ukraine (in Ukrainian).

6. Ermolaev, Y. I., \& Ermolaev, M. Y. (2009). Solnechnyie i mejplanetnyie istochniki geomagnitnyih bur: Aspektyi kosmicheskoy pogodyi. Geofiz. Protsessyi I Biosfera, 8(1), 5-35 (in Russian).

7. Echer, E., \& Gonzalez, W. D. (2004). Geoeffectiveness of interplanetary shocks, magnetic clouds, sector boundary crossings and their combined occurrence. Geophysical Research Letters, 31(9). doi:10.1029/2003gl019199 (in English).

8. Libin, I., Prilutskiy, R., \& Yaani, A. (1989). Vozdeystvie izmeneniy solnechnoy aktivnosti na geofizicheskie i gidrologicheskie protsessyi. I. Spektralnyie harakteristiki kolebaniy vodnosti Chudskogo ozera. Izv. AN Estonii. Biol., 38(2), 97-106 (in Russian). 
9. Libin, I., Prilutskiy, R., \& Yaani, A. (1990). Vozdeystvie izmeneniy solnechnoy aktivnosti na geofizicheskie i gidrologicheskie protsessyi. II. Korotkoperiodnyie kolebaniya vodnosti Chudskogo ozera. Izv. AN Estonii. Geol., 39(3), 98-107 (in Russian).

10. Libin, I. Y., Guschina, R. T., Peres-Peraza, H., Leyva, A., \& Yaani, A. (1996). Vozdeystvie izmeneniy solnechnoy aktivnosti na gidrologicheskie protsessyi: Avtoregressionnyiy analiz solnechnoy aktivnosti i urovney ozer. Geomagnetizm $i$ Aeronomiya, 36, 79-82 (in Russian).

11. Peres-Peraza, J., Leyva, A., \& Zcnteno, G. (1995). Influence of solar activity on hydrological processes: Spectral and autoregressive analysis of solar activity and levels of lakes Patzcuaro and Tchudskoye (p. 24, Rep. No. 95-3). Mexico: UNAM (in English).

12. Dorman, L. I., Libin, I. Y., Mikolayunas, M. M., \& Yudahin, K. F. (1987). Variatsii kosmofizicheskih i geofizicheskih parametrov v 18-21 tsiklah solnechnoy aktivnosti. Geomagnetizm I Aeronomiya, 27(3), 483-485 (in Russian).

13. Tsvyd-Andrew, N. V. (2015). Influence of the solar activity on the hydrometeorological processes. SWorld Journal, J11502, 3-8. Retrieved from http://www.sworldjournal.com/ejoumal/j11502.pdf (in English).

14. Dorman, L. I., Libin, I. Y., Mikolayunas, M. M., \& Yudahin, K. F. (1987). Svyaz kosmofizicheskih i geofizicheskih parametrov v 19-20 tsiklah solnechnoy aktivnosti. Geomagnetizm i aeronomiya, 27(2), 303-305 (in Russian).

15. NOAA (National Centers for Environmental Information) Composite TSI database 1978-present. (n.d.). TSI monitoring by satellite experiments. Retrieved from https://www.ngdc.noaa.gov/stp/solar/solarirrad.html\#composite (in English).

Text of the article was accepted by Editorial Team 30.11.2018

О.В. Альохіна, О.Л. Івантишин, М.М. Корусь, В.В. Кошовий, М.О. Попов, Б.П. Русин

ВПЛИВ ПРИРОДНО-КЛІМАТИЧНИХ ЧИННИКІВ НА КОЛИВАННЯ ВОДНОСТІ ОЗЕР ПРИРОДООХОРОННИХ ТЕРИТОРІЙ

Анотація. У статті розглянуто питання «геліообумовленості» коливань водності озер замкнутого типу на природоохоронних територіях Західного Полісся. Засоби кореляційного аналізу використано для визначення ступеня зв'язку між геліо- i геофізичними процесами в частині впливу на стан екобезпеки території. Встановлено, що параметр сумарної сонячної радіації є більш інформативним, ніж параметр, що враховує лише кількість сонячних плям.

Ключові слова: природоохоронна територія; озеро замкнутого типу; коливання водності; геліообумовленість; кількість сонячних плям; сумарна сонячна радіація; кількість опадів

\section{Альохіна Ольга Володимирівна}

молодший науковий співробітник екологічної лабораторії відділу оптико-електронних інформаційних систем Фізико-механічного інституту ім. Г.В. Карпенка НАН України Адреса робоча: 79060 Україна, м. Львів, вул. Наукова, 5

Тел: (032) 2296518, (032) 2229320, e-mail: alokhina2011 @ gmail.com

ORCID ID 0000-0002-5537-2720

\section{Івантишин Олег Любомирович}

кандидат технічних наук, завідувач радіоастрономічної лабораторії відділу методів і систем дистанційного зондування Фізико-механічного інституту ім. Г.В. Карпенка НАН України

Адреса робоча: 79060 Україна, м. Львів, вул. Наукова, 5

Тел: (032) 2296874,e-mail: oliv@ipm.lviv.ua

ORCID ID 0000-0002-2340-6463 


\section{Корусь Микола Миколайович}

молодший науковий співробітник, інженер I кат. відділу методів і систем дистанційного зондування Фізико-механічного інституту ім. Г.В. Карпенка НАН України

Адреса робоча: 79060 Україна, м. Львів, вул. Наукова, 5

Тел: 032 2296518,e-mail: nikkor2005@ rambler.ru

ORCID ID 0000-0002-8014-5378

\section{Кошовий Володимир Вікторович}

кандидат технічних наук, провідний науковий співробітник відділу методів і систем дистанційного зондування Фізико-механічного інституту ім. Г.В. Карпенка НАН України

Адреса робоча: 79060 Україна, м. Львів, вул. Наукова, 5

Тел: (032) 2637218, (032) 2229320,e-mail: koshovy@ipm.lviv.ua

ORCID ID 0000-0002-4321-4266

\section{Попов Михайло Олексійович}

доктор технічних наук, професор, директор ДУ «Центр аерокосмічних досліджень ІГН НАН України»

Адреса робоча: 01054 Україна, м. Київ, вул. О. Гончара, 55-б

Тел: (044) 482-01-66, e-mail: mpopov@casre.kiev.ua

ORCID ID 0000-0003-1738-8227

\section{Русин Богдан Павлович}

доктор технічних наук, професор, завідувач відділу методів і систем дистанційного зондування Фізико-механічного інституту ім. Г.В. Карпенка НАН України

Адреса робоча: 79060 Україна, м. Львів, вул. Наукова, 5

Тел: (032) 2296113, e-mail: rusyn@ipm.lviv.ua

ORCID ID 0000-0001-8654-2270 